the chief hydrographic nfficer that he, too. was in imminent danger in a heavy gale on the 26th of December, but that, having read what the hydrographic office had said about using oil, he " placed a bag in each closet forward, and let her go southsouth-east," the effect of which was that he shipped no more water.

After all this, I should not wonder if some Jack tar. a little more imaginative than the rest, should outrun all competitors by reporting to the hydrographic office that he had quelled the raging deep merely by carrying a bottle or two of oil in the ship's locker; just as Hahnemann finally found that it was not necessary actually to take his medicine. but that, if the patient only smelled of the phial in which it was contained, it accomplished the same result.

Now, I should seriously like to know whether there is any more credible evidence that oil has a quieting influence upon the ocean than the kind of trash the newspapers are publishing as coming from the hydrographic office.

C. F. Cox.

New York, Jan. 18

Our correspondent assumes a very grave responsibility in trying to throw discredit on the efforts of the hydrographic office to render less dangerous the very hazardous vocation of the sailor. The efficacy of the use of oil to smooth the rough waters has been known for centuries, and the seamen of all countries have been in the habit of resorting to it when the necessity has arisen, although, for the reasons given below, not as freely as would be desirable. The evidence accumulated by the hydrographic office, through its hranches in the seaboard cities, is the result of the first systematic attempt ever made by any government to collect such information, and to disseminate it, in the widest possible manner, among the class most interested. Many seamen have used it with success : and most, having heard of its value ever since boyhood, have always intended to use it on occasion. It must be borne in mind, however, that there is much to be done on hoard a ship undergoing all the vicissitudes incident to a yale of wind ; and, unless the captain bas had previnus expertence, be is not likely to think of experimenting when there is so much to do which he knows to be necessary. Seamen, also, though given to the telling of 'yarns,' are slow to believe them, a very harsh and trying experience making this class most incredulous and conservative.

The life-saving services of this country and Great Britain have made experiments with a view to demonstrating the usefulness of oil in quelling the surf. The results, however, have been unsatisfactory; yet this investigation led them incidentally into the subject of its usefulness off shore with most satisfactory results. The report to the superintendent of the U.S. life-saving service in 1883 , of a committee appointed to examine this matter, states in conclusion, "The majority of the printed statements herewith, assuming them to be authentic. together with all verbal statements made by mariners who have used it. furnish conclusive evidence that in deep water oil has a calming effect upon a rough sea."

In an article published in the Nineteenth century for April, 1882, Mr. C. F. Gordon Cumming states that "it is now many years since I first endeavored to call public attention to the simple precaution." "Though the casting of uil on troubled waters has been so persistently regarded merely as a poetical figure of speech, notes of its actual use have oc sasionally appeared in books of travel ;" and, again, "It has been reserved for the nineteenth century to find the practical application of the observations made by Pliny eighteen hundred years ago." The corre. spondent's confessed want of knowledge of the sea leads him very properly to make inquiries in regard to its 'prodigies und marvels;' but his sympathy should restrain him from decrying any attempt to benefit a class which, on the whole, gets a very small share of the substantial comforts of life.-ED.]

The following is a letter received at the Boston branch of the hydrographic office :-

On Nov. 28, 1885, I left Boston for London, deep with general cargo, and cattle and sheep on the upper deck. At 8.30 P M. of Dec. 4 we were caught in a heavy storm at W. N. W., bar. 2920 . The first hour of the storm no canvass could stand it. In lat. $44^{\circ}$ $38^{\prime}$ and long. $48^{\circ} 28^{\prime}$ W., ship running under bare poles, the sea was then so high and dangerous. I resolved to try the use of oil, having had it brought to my notice by information on your chart. I gnt two common gunny-bags and a good wad of oakum wrung out in paint oil, and hung over each quarter, just dipping in the water, also one over by che scuppers in the midships. At 10 P.M. I got the lower topsail set. and continued to run until noon next day. By the racing of the engines my engineer reported to me that he could not run much longer. as the packing of the gland of the high-pressure engine was all worn out. I then got two more farther forward with a hand in each water-closet forward, dropping oil through ; by this means she kept steady on ber course, engines stopped, and sailing 6 knots. while the engineer did his work comfortably. I landed the whole of my cattle alive at Deptford, and never broke any of the cattle-pens.

The use of oil I strongly recommend in an emergencr : a smali drip is of no use. I used one gallon per hour, and had the watch continually going round attending one bay after another.

The result you know, and I.hope it will be of use to shipmasters.

Furness line, SS. Stnckholm City,

$$
\text { Boston, Jan. } 17 .
$$

\section{The Taconic controversy in a nutshell.}

In Science, No. 153, Prof. N. H. Winchell, in writing under the above head, presents a very timely demurrer against the injustice done to the memory of Professor Emmons in ignoring the name 'Taconic,' and substituting 'Cambrian,' and several other designations, for pre-Potsdam formations other than Archaean.

In referring to recent studies of rorks that have been claimed as part of the Taconic by Emmons, Professor Winchell writes, "Some of the opponents of Emmons, re-enforced lately by active, younger men, revive the fossiliferous character of some of the eqstern belts as new matter, adding many interesting and valuable details, and begin again to fire at the old fort long ago abandoned by Emmons, insisting that Emmons is still intrenched there (1872-85)."

I have several reasons for thinking that $I$ have been understood to have taken a stand as part of the re-enforcement, because of my having recently published a paper on the subject mentioned, and entitled "On the occurrence of fossils in the "Hudson 